\title{
Determination of Methyldopa in Pharmaceutical Formulations by Combined Spot Test-Diffuse Reflectance Spectroscopy
}

\author{
Paulo Roberto S. Ribeiro, Leonardo Pezza and Helena R. Pezza* \\ Instituto de Química, Universidade Estadual Paulista, CP 355, 14801-970 Araraquara-SP, Brazil
}

\begin{abstract}
Este trabalho descreve um método simples e rápido por "spot test" quantitativo, utilizando a espectroscopia de reflectância difusa para determinação de metildopa em formulações farmacêuticas. O método proposto baseia-se na reação de complexação entre metildopa e íons molibdato, formando um complexo amarelo na superfície do papel de filtro. As medidas de reflectância foram realizadas a $410 \mathrm{~nm}$. A curva analítica obtida a partir do gráfico de densidade óptica do sinal de reflectância $\left(\mathrm{A}_{\mathrm{R}}\right)$ vs. $\log$ da concentração de metildopa apresentou linearidade na faixa de $6,30 \times 10^{-3}$ a $1,89 \times 10^{-2} \mathrm{~mol} \mathrm{~L}^{-1}$, com um coeficiente de correlação de 0,998 . $\mathrm{O}$ limite de detecção foi de $2,74 \times 10^{-3} \mathrm{~mol} \mathrm{~L}^{-1}$ (R.S.D. $=1,02 \%$ ). As substâncias comumente utilizadas como excipientes nas formulações farmacêuticas não interferem no método proposto. O método foi aplicado para a determinação de metildopa em formulações farmacêuticas comerciais. Os resultados obtidos por este método foram comparados favoravelmente com aqueles obtidos pelo método oficial, com $95 \%$ de nível de confiança.
\end{abstract}

This paper describes a very simple and rapid quantitative reflectance spot test procedure for the determination of methyldopa in pharmaceutical formulations. This method is based on the complexation reaction of methyldopa with molybdate ions yielding a yellow stable complex on filter paper. Reflectance measurements were carried out at $410 \mathrm{~nm}$. Under optimal conditions, the calibration graphs obtained for methyldopa by plotting the optical density of the reflectance signal $\left(\mathrm{A}_{\mathrm{R}}\right) v$ s. the log of the concentration were linear from $6.30 \times 10^{-3}$ to $1.89 \times 10^{-2} \mathrm{~mol} \mathrm{~L}^{-1}$, with a correlation coefficient of 0.998 . The detection limit was $2.74 \times 10^{-3} \mathrm{~mol} \mathrm{~L}^{-1}$ (R.S.D. $=$ $1.02 \%$ ) for methyldopa. The common excipients used as additives in pharmaceuticals do not interfere in the proposed method. The method was applied to determine metyldopa in commercial pharmaceutical formulations. The results obtained by the proposed method compare favorably with those obtained by an official procedure at $95 \%$ confidence level.

Keywords: methyldopa, diffuse reflectance, pharmaceuticals formulations

\section{Introduction}

Methyldopa ( $\alpha$-methyl-3,4-dihydroxyphenylalanine, MTD) is a catechol derivative (catecholamine) widely used as antihypertensive agent. The MTD is a centrally acting alpha ${ }_{2}$-adrenoreceptor agonist, which reduces sympathetic tone and produces a fall in blood pressure. ${ }^{1}$

Several analytical methods have been reported for the quantitative determination of methyldopa in pharmaceutical formulations. These methods included titrimetry, ${ }^{2-7}$ fluorimetry, ${ }^{8}$ kinetics measurements, ${ }^{9}$ amperometry, ${ }^{10}$ gas chromatography, ${ }^{11,12}$ high-performance liquid chromatography (HPLC), ${ }^{13,14}$ chemiluminescence, ${ }^{15,16}$ voltammetry ${ }^{17}$ and spectrophotometry. ${ }^{3-7,18-33}$ Some of these methods are not

* e-mail: hrpezza@iq.unesp.br simple; others are time consuming or involve procedures with rigorous control of the experimental conditions or suffer interference from the tablet matrix and consequently are not suitable for routine analysis. Most of the titrimetric methods reported $^{3-7}$ were indirect titrations and based in reduction reactions, which present interferences of unsaturated organic compounds. The official method reported in $\mathrm{USP}^{2}$ describes a nonaqueous titration for the assay of MTD.

In recent years more and more strict regulations related to the quality control of pharmaceuticals led to increasing demands on the simplicity and rapidity of analytical assay ${ }^{34,35}$ Considering the simplicity of the spot test method, the use of small quantities of chemicals, the confidence and the rapidity of such kind of procedure, the quantitative spot-test analysis by diffuse reflectance spectroscopy could be interesting to develop analytical procedures for routine analysis of drugs in pharmaceuticals formulations. 
For many years, the use of reflectance spectroscopy as an analytical technique was limited to paints, pigments, paper, ceramic and textile areas. However, with the development of optical devices including optical fibers ${ }^{36}$ and reflectance spheres, ${ }^{37-40}$ the situation has changed and acceptable results were obtained.

Several quantitative reflectometric methods have been reported in the literature. The exact value for the absolute reflectance of $\mathrm{KBr}$ powder was utilized to detect a low concentration of dioctyl phthalate. ${ }^{41}$ The properties of redox media equilibrium of some quinonoid indicators were studied when they are immobilized by adsorption on XAD2 , synthetic copolymer, by reflectometry measurement. ${ }^{42}$ The determination of $\mathrm{Ni}(\mathrm{II}), \mathrm{Fe}(\mathrm{III})$ and $\mathrm{Cr}(\mathrm{VI}),{ }^{37}$ hydrogen chloride, ${ }^{43}$ cations, ${ }^{44}$ and free active chlorine, ${ }^{45}$ in water, ammonium, phosphate and $\mathrm{Cu}(\mathrm{II}),{ }^{46} \mathrm{Fe}(\mathrm{III}),{ }^{47} \mathrm{Cr}(\mathrm{VI}),{ }^{48}$ acetylsalicylic acid ${ }^{49}$ and furosemide in pharmaceutical formulations ${ }^{50}$ by reflectance spectroscopy were related. Moreover, a multiplexed colorimetric solid-phase extraction for determination of $\mathrm{Ag}(\mathrm{I}), \mathrm{Ni}(\mathrm{II})$, and sample $\mathrm{pH}$ by diffuse reflection spectroscopy was developed ${ }^{51}$ and the interaction of aqueous iodine solutions with immobilized poly(vinylpyrrolidone) (PVP) by diffuse reflection spectroscopy was investigated. ${ }^{52}$ To the best of our knowledge, there are no reports on the use of quantitative spot test by diffuse reflectance for the determination of methyldopa in pharmaceutical formulations.<smiles>CC(N)(Cc1ccc(O)c(O)c1)C(=O)O</smiles>

Figure 1. Chemical structure of methyldopa.

It has long been known that molybdate can react with catechol to form colored complexes. ${ }^{53,54}$ The cathecolate functionalities on the MTD ligand (Figure 1) suggest that it is capable of binding at available coordination sites on a cisdioxo $\mathrm{Mo}(\mathrm{VI})$ center to produce species analogous to the well known bis(catecholate)complex, $\mathrm{MoO}_{2}(\mathrm{cat})_{2}{ }^{2-}$ $\left(\mathrm{H}_{2} \mathrm{cat}=\mathrm{catechol}\right){ }^{54} \mathrm{In}$ previous studies, a spectrophotometric method $^{55}$ and a flow-injection analysis procedure ${ }^{56}$ by using this reaction was developed in this laboratory. The combined spot test-diffuse reflectance spectroscopy offers advantages over the mentioned spectrophotometric method, such as simplicity and extremely low consumption of reagents. The flow injection procedure can not be performed in locus. In this aspect, quantitative spot test procedures can be a very good alternative when combined with diffuse reflectance spectroscopy. The reflectance measurements can be performed by using a very simple homemade reflectometer or a portable diffuse reflectance spectrophotometer, ${ }^{57}$ which are small, lightweight, inexpensive and battery operated, characteristics highly attractive for many applications in any location by nearly everyone.

In the present work, a quantitative spot test procedure carried out by measuring the reflectance of the color developed in complexation reaction of MTD with molybdate ions is described. This method is simple, rapid, inexpensive and does not involve any pre-treatment procedure or heating steps. The results obtained by the proposed method were in excellent agreement with those given by the official method, ${ }^{33}$ proving that the method is a reliable alternative for the analysis of methyldopa in pharmaceutical formulations.

\section{Experimental}

\section{Apparatus}

Volume measurements were made with "Eppendorf" plunger-operated pipetter $(10-100 \mu \mathrm{L})$. A Labsphere RSA-HP-8453 reflectance sphere integrator $(76 \mathrm{~mm}$ diameter, 5W halogen source) coupled to a Hewlett Packard HP 8453A diode array spectrophotometer was used for all reflectance measurements. All experiments were performed in a thermostated room $(25 \pm 1)^{\circ} \mathrm{C}$.

\section{Reagents and solutions}

Analytical reagent or pharmaceutical grade chemicals were used. For the preparation of the solutions and samples, deionised water and grade A glassware were used throughout. Whatman 41 filter paper was used as solid support.

Methyldopa standard was purchased from Purifarma, Brazil, (purity > 99.99\%). A $2.1 \times 10^{-2} \mathrm{~mol} \mathrm{~L}^{-1}$ stock solution of MTD was freshly prepared. This solution was standardized according the literature. ${ }^{33}$ Working standard solutions were obtained by appropriate dilution of this stock solution in water.

Ammonium molybdate $\left[\left(\mathrm{NH}_{4}\right)_{6} \cdot \mathrm{Mo}_{7} \cdot \mathrm{O}_{24} \cdot 4 \mathrm{H}_{2} \mathrm{O}\right]$ was purchased from Merck (Darmstadt, Germany, p.a.). The ammonium molybdate aqueous solution $1.0 \%(\mathrm{~m} / \mathrm{v})$ was prepared daily.

Four commercial samples (A - D) of MTD containing 250 or 500 mg MTD per unit were purchased from local drugstores in Araraquara, Brazil.

\section{Recommended procedure for the calibration curve}

For the spot reaction, $20 \mu \mathrm{L}$ of the analyte solution was spotted onto $1 \mathrm{~cm}^{2}$ Whatman 41 filter paper followed by addition of $20 \mu \mathrm{L}$ of the reagent solution. The solutions 
were dropped onto the paper with a micropipette fixed in a holder according to procedure described by Tubino et $a .^{37}$ and the reflectance measurements were carried out at $410 \mathrm{~nm}$ after $15 \mathrm{~min}$. The blank solution is prepared in a similar way, but omitting MTD. Calibration graphs are prepared by plotting the optical density of the reflectance signal $\left(A_{R}\right)$ vs. the log of the mol L-1 drug concentration. These graphs or the corresponding linear least squares equations are used to convert reflectance into MTD concentration, for any analysed sample.

\section{Procedure for the assay of MTD in pharmaceutical samples}

Twenty tablets of each commercial brand of MTD were weighed and finely powdered. A portion of this powder, equivalent to approximately $125.0 \mathrm{mg}$ of MTD was accurately weighed and dissolved with $35 \mathrm{~mL}$ of water by shaking for $15 \mathrm{~min}$ in a mechanical shaker. The resulting mixture was transferred into $50 \mathrm{~mL}$ standard flask and the volume completed with deionised water. An aliquot of this solution was taken for the spot test reflectance analysis according to the recommended procedure.

\section{Study of interferences}

Since the aim of this study was to determine MTD in pharmaceuticals, the effects of the most commonly used excipients were carefully examined. The excipients studied were sucrose, glucose, talc, fructose, lactose, poly(ethylene glycol), microcrystalline cellulose, croscarmellose sodium, starch, polyvinylpyrrolidone and magnesium stearate. For this study, solutions containing MTD and each of the excipients taken separately in concentrations equal or 10 times greater than that of MTD were shaken with water in a magnetic mixer for 15 minutes, diluted and analyzed under the same conditions described in recommended procedure.

\section{Results and Discussion}

The method involves the complexation reaction of MTD with molybdate ions to produce yellow coloured product, in aqueous media. The reflectance spectrum of the reaction product shows that the best analytical wavelength is located at $410 \mathrm{~nm}$.

Investigations were carried out to establish the optimum conditions for complex formation. Thus, the influence of the molybdate concentration on the reaction was studied in order to achieve maximum absorbance, repeatability, stability, sensitivity and linearity. The solutions of this reagent were evaluated in the following concentrations: $5.0 \times 10^{-2}, 2.5 \times 10^{-1}, 5.0 \times 10^{-1}, 1.0,2.0$, 4.0, 8.0 and $10.0 \%(\mathrm{~m} / \mathrm{v})$. The $1.0 \%$ ammonium molybdate solution was found to be sufficient for providing maximum and reproducible color intensity.

\section{Analytical curves and stability}

Under optimized experimental conditions, a series of standard solutions was analyzed to test the linearity. The calibration curve (Figure 2) was found to be linear in the $6.30 \times 10^{-3}-1.89 \times 10^{-2} \mathrm{~mol} \mathrm{~L}^{-1}$ concentration range $\left(A_{R}=\right.$ $-0.6674+0.4644 \times \mathrm{C} ; \mathrm{r}=0.998)$, where $A_{R}$ is the reflectance measurement to $410 \mathrm{~nm}$ and $\mathrm{C}=\log \left(10^{4}[\mathrm{MTD}] / \mathrm{mol} \mathrm{L}^{-1}\right)$. The factor $10^{4}$ was used to adjust the calibration graph to $\log$ values higher than zero. The limit of detection was estimated to be $2.74 \times 10^{-3} \mathrm{~mol} \mathrm{~L}^{-1}$ (R.S.D. $=1.02 \%$ ), according to the analytical curve data and using the criteria of the mathematical model given by Miller and Miller. ${ }^{58}$

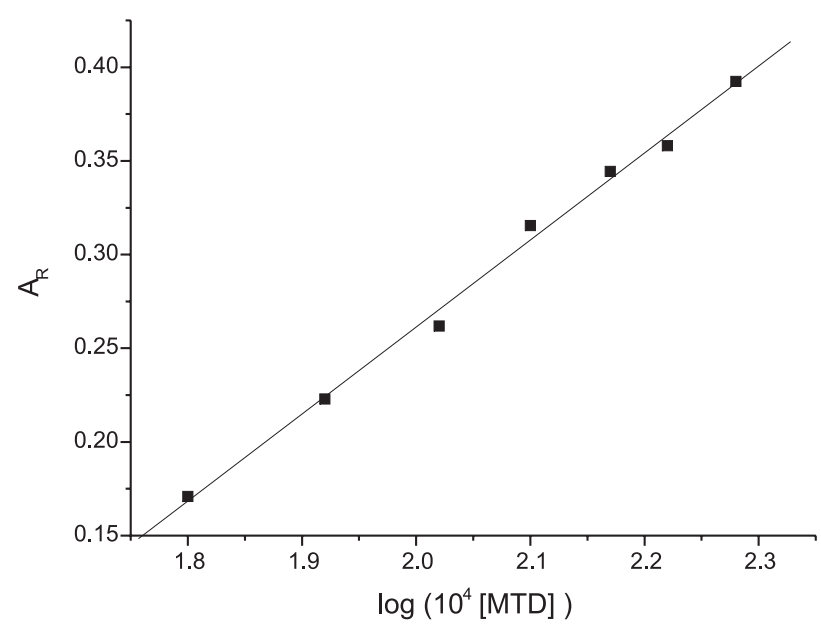

Figure 2. Calibration curve for methyldopa. Formation of yellow coloured product on filter paper square $\left(1 \mathrm{~cm}^{2}\right) . A_{R}$ values were taken at $410 \mathrm{~nm}$. The concentration of methyldopa, [MTD], is given in $\mathrm{mol} \mathrm{L}^{-1}$.

The data given in Table 1 show that the color development is immediate at room temperature $\left(25 \pm 1^{\circ} \mathrm{C}\right)$, but the stability of color was obtained after 15 min. The resulting chromogen is stable for at least 60 min at room temperature. In this manner, all intensity reflectance values were taken after 15 minutes, the drying time of filter paper. Alternatively, using a hair-dryer this time is reduced for 25 seconds, without any alteration in the intensity of the reflectance measurement.

\section{Effect of interferences, repeatability and recovery studies}

The influence of excipients that commonly accompany MTD in pharmaceutical formulations was studied. No interference in the proposed method was observed up to $c a$. 10-fold excess of sucrose, glucose, talc, fructose, lactose, 
Table 1. Reflectance measurements at room temperature $\left(25 \pm 1{ }^{\circ} \mathrm{C}\right)$ as related to the time of reaction ${ }^{\mathrm{a}}$

\begin{tabular}{cc}
\hline time $(\min )$ & $\mathrm{A}_{\mathrm{R}}^{\mathrm{b}}$ \\
\hline 0 & 0.51780 \\
5 & 0.45168 \\
10 & 0.36527 \\
15 & 0.33296 \\
20 & 0.33904 \\
25 & 0.33196 \\
30 & 0.33267 \\
$35^{\mathrm{c}}$ & 0.33319 \\
\hline
\end{tabular}

aMD concentration: $1.68 \times 10^{-2} \mathrm{~mol} \mathrm{~L}^{-1}$; ${ }^{\text {b }}$ measurements taken at 410 $\mathrm{nm}$ against the reagent blank for reactants at room temperature $(25 \pm 1$ ${ }^{\circ} \mathrm{C}$ ), as described in the recommended procedure; ${ }^{\mathrm{c}}$ the reflectance remains unchanged after standing for $60 \mathrm{~min}$ at $25^{\circ} \mathrm{C}$.

poly(ethylene glycol), microcrystalline cellulose, croscarmellose sodium, starch, polyvinylpyrrolidone and magnesium stearate.

The area of solid support used for spot test is very important. In this work we observed that good reflectance readings could be assured if $1 \mathrm{~cm}^{2}$ sized pieces of good quality filter paper are used as support for the spot test reactions. The most important thing here is the uniformity of the spot color test over the entire surface. In the repeatability study, the R.S.D. was $3 \%$ for solutions containing equivalent to $1.68 \times 10^{-2} \mathrm{~mol} \mathrm{~L}^{-1}$ of MTD $(n=10)$. This is good evidence of repeatability of the proposed method.

To study the recovery of the MTD from pharmaceuticals formulations, four commercial samples were used. The recovery of MTD was examined by adding MTD reference solutions at four levels $\left(4.20 \times 10^{-3}\right.$, $6.30 \times 10^{-3}, 8.40 \times 10^{-3}$ and $\left.10.5 \times 10^{-3} \mathrm{~mol} \mathrm{~L}^{-1}\right)$ to the samples containing equivalent to $8.40 \times 10^{-3} \mathrm{~mol} \mathrm{~L}^{-1}$ MTD. The results obtained (Table 2) were compared with the added concentrations. The average recoveries obtained ranged from 100.1 to $101.0 \%$, evidencing the absence of matrix effect on the proposed method.

\section{Analytical applications}

In order to assess the utility of the presently developed method it was applied to the determination of methyldopa in pharmaceutical formulations. The results, presented in Table 3, compare favorably with the official method of the Brazilian Pharmacopoeia. ${ }^{33}$ Statistical analysis of the results obtained by the proposed and official methods using $t$-test and $F$-test ${ }^{58}$ showed no significant difference between the performances of these methods, for $95 \%$ confidence level.

\section{Conclusions}

In the present study, we have demonstrated the potential of diffuse reflectance spectroscopy for the analysis of methyldopa in pharmaceutical preparations. The results obtained from the present study showed the good performance of this technique, suggesting its use as an advantageous alternative for quantitative analytical purposes.

Table 2. Results of the addition-recovery experiments

\begin{tabular}{|c|c|c|c|}
\hline Sample & Added $\left(10^{-3} \mathrm{~mol} \mathrm{~L}^{-1}\right)$ & Found $\left(10^{-3} \mathrm{~mol} \mathrm{~L}^{-1}\right)$ & Recovery (\%) \\
\hline \multirow[t]{6}{*}{ A } & 0.00 & 8.35 & - \\
\hline & 4.20 & 12.72 & 101.0 \\
\hline & 6.30 & 14.90 & 101.4 \\
\hline & 8.40 & 16.80 & 100.0 \\
\hline & 10.5 & 18.97 & 100.4 \\
\hline & & & $\mu^{\mathrm{a}}=100.7 \pm 0.6$ \\
\hline \multirow[t]{6}{*}{ B } & 0.00 & 8.49 & - \\
\hline & 4.20 & 12.80 & 101.6 \\
\hline & 6.30 & 14.59 & 99.2 \\
\hline & 8.40 & 16.98 & 101.1 \\
\hline & 10.5 & 19.31 & 102.2 \\
\hline & & & $\mu^{\mathrm{a}}=101.0 \pm 1.3$ \\
\hline \multirow[t]{6}{*}{$\mathrm{C}$} & 0.00 & 8.27 & - \\
\hline & 4.20 & 12.54 & 99.5 \\
\hline & 6.30 & 14.83 & 100.9 \\
\hline & 8.40 & 16.99 & 101.1 \\
\hline & 10.5 & 18.72 & 99.0 \\
\hline & & & $\mu^{\mathrm{a}}=100.1 \pm 1.0$ \\
\hline \multirow[t]{6}{*}{ D } & 0.00 & 8.53 & - \\
\hline & 4.20 & 12.78 & 101.4 \\
\hline & 6.30 & 14.94 & 101.6 \\
\hline & 8.40 & 16.66 & 99.2 \\
\hline & 10.5 & 18.98 & 100.4 \\
\hline & & & $\mu^{\mathrm{a}}=100.6 \pm 1.1$ \\
\hline
\end{tabular}

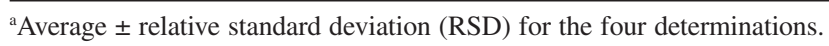


Table 3. Determination of MTD in commercial pharmaceutical preparations

\begin{tabular}{|c|c|c|c|c|c|c|c|}
\hline \multirow[t]{2}{*}{ Sample } & \multirow[t]{2}{*}{ Label value ${ }^{a}$} & \multicolumn{4}{|c|}{ Proposed method } & \multicolumn{2}{|c|}{ Official method ${ }^{33}$} \\
\hline & & Found $^{b}$ & $\operatorname{RSD}(\%)^{\mathrm{c}}$ & $t$-value $(2.45)^{\mathrm{d}}$ & $F$-value $(9.28)^{\mathrm{d}}$ & Found $^{\mathrm{b}}$ & $\operatorname{RSD}(\%)^{\mathrm{c}}$ \\
\hline A & 250.0 & $253.0 \pm 1.8$ & 0.7 & 1.05 & 4.00 & $256.3 \pm 0.9$ & 0.4 \\
\hline B & 250.0 & $254.3 \pm 4.3$ & 1.7 & 1.27 & 7.22 & $258.3 \pm 1.6$ & 0.6 \\
\hline $\mathrm{C}$ & 500.0 & $498.6 \pm 2.8$ & 0.6 & 1.81 & 2.42 & $510.3 \pm 1.8$ & 0.4 \\
\hline D & 500.0 & $509.3 \pm 7.9$ & 1.6 & 0.55 & 1.30 & $513.9 \pm 9.0$ & 1.7 \\
\hline
\end{tabular}

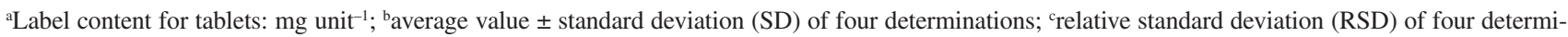
nations; 'dthe figures between parentheses are the theoretical values of $t$ and $F$ at $P=0.05$.

The proposed method results a simple, fast, inexpensive, precise and accurate analytical technique to determine MTD in commercial pharmaceutical preparations with satisfactory recoveries. Moreover, it does not require the removal of usual excipients present in pharmaceutical formulations since they were found not to interfere with the determination of MTD.

\section{Acknowledgments}

We would like to thank FUNDUNESP, CAPES, CNPq and FAPESP Foundations (Brazil) for financial support.

\section{References}

1. Hoffman, B. B.; Lefkowitz, R. J. In The Pharmacological Basis of Therapeutics, $9^{\text {th }}$ ed.; Gilman, A. G.; Hardman, J. G.; Limbird, L. E.; Molinoff, P. B.; Ruddon, R. W., eds.; MacGraw-Hill: New York, 1996, ch. 10.

2. The United States Pharmacopoeia, $24^{\text {th }}$ ed.; The United States Pharmacopoeial Convention: Rockville, MD, 2000.

3. Amin, D.; Analyst 1986, 111, 255.

4. Walash, M. I.; Abououf, A.; Salem, F. B.; J. Assoc. Off. Anal. Chem. 1982, 65, 1445.

5. Mohamed, W. I.; Salem, F. B.; Anal. Lett. 1984, 17, 191.

6. Salem, F. B.; Talanta 1987, 34, 810.

7. Salem, F. B.; Anal. Lett. 1993, 26, 1959.

8. Salem, F. B.; Anal. Lett. 1993, 26, 281.

9. Martinez-Lozano, C.; Pérez-Ruiz, T.; Tomas, V.; Val, O.; Analyst 1991, 116, 857.

10. Garrido, M. E.; Lima, J. L. F. C.; Delerue-Mattos, C.; J. Pharm. Biom. Anal. 1997, 15, 845.

11. Sharma, C.; Mohanty, S.; Kumar, S.; Rao, N. J.; Analyst 1996, 121, 1963.

12. Lee, H. B.; Hong-You, R. L.; Fowlie, P. J. A.; J. Assoc. Off. Anal. Chem. 1989, 72, 979.

13. Tsuchiya, H.; Sato; M.; Kato, H.; Okubo, T.; Juneja, L. R.; Kim, M.; J. Chromatogr. B 1997, 703, 253.

14. Parsons, L. H.; Kerr, T. M.; Weiss, F.; J. Chromatogr. B 1998 , 709, 35.

15. Nozaki, O.; Iwaeda, T.; Kato, Y.; J. Biolumin. Chemilumin. 1996, 11, 309.
16. Nozaki, O.; Iwaeda, T.; Moriyama, H.; Kato, Y.; Luminescence 1999, 14, 123.

17. Kozminski, K. D.; Gutman, D. A.; Davila, V.; Sulzer, D.; Ewing, A. G.; Anal. Chem. 1998, 70, 3123.

18. Davidson, A. G.; J. Pharm. Sci. 1984, 73, 1582.

19. Salem, F. B.; Anal. Lett. 1985, 18, 1063.

20. Nevado, J. J. B.; Gallego, J. M. L.; Laguna, P. B.; Frenesius J. Anal. Chem. 1995, 353, 221.

21. Mohamed, W. I.; Salem, F. B.; Anal. Lett. 1984, 17, 191.

22. El-Rabbat, N. A.; Omar, N. M.; J. Pharm. Sci. 1978, 67, 779.

23. Issopoulos, P. B.; Frenesius J. Anal. Chem. 1990, 336, 124.

24. Zivanovic, L.; Vasiljevic, S.; Radulovic, D.; Boll. Chim. Farm. 1991, 130, 162.

25. Aman, T.; Khan, I. U.; Aslam, N.; Ahmed, I.; Anal. Lett. 1998, 31, 1007.

26. Nagaraja, P.; Murthy, K. C. S.; Rangappa, K. S.; Gowda, N. M. M.; Talanta 1998, 46, 39.

27. Vieira, I. C.; Fatibello-Filho, O.; Talanta 1998, 46, 559.

28. Nagaraja, P.; Vasantha, R. A.; Sunitha, K. R.; Talanta 2001, 55,1039

29. Issopoulos, P. B.; P. Economou, T.; Farmaco 1993, 48, 127.

30. Nagaraja, P.; Vasantha, R. A.; Murthy, K. C. S.; Rangappa, K. S.; Chemia Analityczna 2001, 46, 569.

31. Gowda, B. G.; Melwanki, M. B.; Seetharamappa, J.; Anal. Sci. 2001, 17, 533.

32. Issopoulos, P. B.; Pharm. Acta Helv. 1989, 64, 82.

33. Farmacopéia Brasileira, $4^{\text {th }}$ ed., Atheneu Editora São Paulo: São Paulo, 1996.

34. Jungreis, E.; Spot Test Analysis, $2^{\text {nd }}$ ed., John Wiley \& Sons: New York, 1997.

35. Song, Z.; Zhang, N.; Talanta 2003, 60, 161.

36. Narayanaswamy, R.; Analyst 1993, 118, 317.

37. Tubino, M.; Rossi, A. V.; De Magalhães, M. E. A.; Anal. Lett. 1997, 30, 271.

38. Hecht, H. G.; Appl. Spectrosc. 1983, 37, 348.

39. Ditzler, M. A.; Allston, R. A.; Casey, T. J.; Spellman, N. T.; Willis, K. A.; Appl. Spectrosc. 1983, 37, 269.

40. Ghauch, A.; Rima, J.; Amine, C.; Martin-Bouyer, M.; Chemosphere 1999, 39, 1309.

41. Reinecke, D.; Jensen A.; Fister, F.; Scherman, U.; Anal. Chem. 1988, 60, 1221. 
42. Narayanaswamy, R.; Sevilla, F.; Anal. Chim. Acta 1986, 189, 365.

43. Nakano, N.; Yamamoto, A.; Kobayashi, Y.; Nagashima, K., Analyst 1993, 118, 1539.

44. Ghauch, A.; Turnar, C.; Fachinger, C.; Rima, J.; Charef, A.; Suptil, J.; Martin-Bouyer, M.; Chemosphere 2000, 40, 1327.

45. Dmitrienko, S. G.; Sviridova, O. A.; Pyatkova, L. N.; Zhukova, V. A.; Anal. Chim. Acta 2000, 405, 231.

46. Ghauch, A.; Rima, J.; Charef, A.; Suptil, J.; Fachinger, C.; Martin-Bouyer, M.; Talanta 1999, 48, 385.

47. Kompany-Zareh, M.; Mansourian, M.; Ravaee, F.; Anal. Chim. Acta 2002, 471, 97.

48. Savvin, S. B.; Trutneva, L. M.; Shvoeva, O. P.; J. Anal. Chim. 1993, 48, 358.

49. Matias, F. A. A.; Vila, M. M. D. C.; Tubino, M.; J. Braz. Chem. Soc. 2004, 15, 327.

50. Gotardo, M. A.; Gigante, A. C.; Pezza, L.; Pezza, H. R., Talanta 2004, 64, 361 .
51. Gazda, D. B.; Fritz, J. S.; Porter, M. D.; Anal. Chem. 2004, 76, 4881.

52. Gazda, D. B.; Lipert, R. J.; Fritz; J. S.; Porter, M. D.; Anal. Chim. Acta 2004, 510, 241.

53. Haight, G. P.; Paragamian, V.; Anal. Chem. 1960, 32, 642.

54. Kustin, K.; Liu, S. T.; J. Am. Chem. Soc. 1973, 95, 2487.

55. Ribeiro, P.R.S.; Pezza, L.; Pezza, H.R.; Ecletica Quimica 2005, 30, 23.

56. Ribeiro, P.R.S.; Gomes Neto, J.A.; Pezza, L.; Pezza, H.R.; Talanta 2005, 67, 240.

57. Dias, N.C.; Porter, M.D.; Fritz, J.S.; Anal. Chim. Acta 2006, 558, 230.

58. Miller, J. C.; Miller J. N.; Estadística para Química Analítica, $2^{\text {nd }}$ ed., Addison-Wesley Iberoamericana: Delaware, 1993.

Received: December 5, 2005

Published on the web: May 11, 2006

FAPESP helped in meeting the publication costs of this article. 